\title{
Mating behaviour and insemination in the hopping mouse (Notomys alexis)
}

\author{
W. G. Breed and J. M. Washington \\ Department of Anatomy \& Histology, Adelaide University, North Terrace, Adelaide, \\ South Australia 5000
}

\begin{abstract}
Summary. Hopping mice have extremely small testes and a reduced complement of male accessory sex glands. Nevertheless, $>1000$ spermatozoa populate the isthmus of the oviduct after each insemination and a range of morphological types is found similar to that in the male tract. When females are primed with gonadotrophins they sometimes lock with more than one of the males within the group and in the present study two inseminations sometimes took place at the one oestrus. There is thus the possibility for intermale sperm competition within the female tract of these animals.
\end{abstract}

Keywords: sperm abundance; mating system; hopping mouse

\section{Introduction}

The theory of sexual selection predicts that males will compete between each other to fertilize the eggs of females. In many mammalian species, male-male competition to gain access to females results in the evolution of aggressiveness and sexually dimorphic characters including larger body mass than that of females. However, it is becoming increasingly apparent that dominant males in a breeding group, or even a male in a monogamous pair, may not have sole mating rights of a particular female at oestrus (see Birkhead, 1987). Intermale sperm competition may thus take place within the female reproductive tract after inseminations by two or more males. It is thought that this may lead to the evolution of relatively larger testes in species that exhibit a multimale mating system, as the greater the amount of tissue producing germ cells the more spermatozoa are likely to be produced and, all other things being equal, the greater the chances of that male fertilizing the eggs of the female (Short, 1979, 1980; Harcourt et al., 1981; Harvey \& Harcourt, 1984; Kenagy \& Trombulak, 1986). Møller $(1988,1989)$ has shown that species with relatively large testes tend to produce higher quality, and ejaculate more spermatozoa.

Although number of spermatozoa deposited is likely to be one component that determines the chances of a particular male fertilizing the eggs of the female (Parker, 1984), there are clearly several other factors that need to be considered (see Huck et al., 1985; Ginsburg \& Huck, 1989; Birkhead \& Hunter, 1990). For instance, spermatozoa from the first male may have precedence over subsequent ejaculates because of the presence of certain protective mechanisms, such as a vaginal plug or some other 'chastity enforcing' device (Voss, 1979), and it has been suggested that spermatozoa not involved in fertilizing the eggs may form a partial barrier to spermatozoa from any other ejaculates (Baker \& Bellis, 1988). These devices may not, however, be infallible (see Dewsbury, 1984, 1988) and mechanisms may also evolve for removal of such protective devices. In other situations, therefore, spermatozoa from the last male to mate with the female may fertilize most of the ovulated eggs. Clearly, selective pressures for the evolution of such mechanisms are likely to be more intense in species that exhibit a polyandrous or promiscuous mating system than in monogamous species. 
Much credence for the sexual selection theory of the evolution of testis size and breeding system in mammals has come from work on primates (e.g. Short, 1979; Harcourt et al., 1981; Kenagy \& Trombulak, 1986; Møller, 1988, 1989). In Australia there are several species of small conilurine murid rodents that have remarkable differences in absolute and relative testis size as well as in numbers of stored spermatozoa in the excurrent ducts. The two species in our laboratory, Pseudomys australis and Notomys alexis, are at opposite ends of the spectrum with regard to these parameters (Breed, 1982, 1986; Pierce \& Breed, 1987, 1989). The testis mass of P. australis is about three times greater, whereas that of $N$. alexis is ten times less, than that expected for their respective body weights (Kenagy \& Trombulak, 1986). Apart from having relatively small testes, $N$. alexis males also have very small epididymides (Breed, 1982; Peirce \& Breed, 1989) and highly pleiomorphic spermatozoa in the excurrent ducts (Breed \& Sarafis, 1983; Suttle et al., 1988). It would thus be expected that this species would have low or no intermale sperm competition and the breeding system is, perhaps, likely to be one in which monogamous or single-male breeding groups occur. However, we have found that, when groups of adult laboratory-bred hopping mice of both sexes are placed together in the same cage, a single female may sometimes lock with two of the males at the one oestrous period. Locking, however, does not invariably result in ejaculation and in no instance did two males deposit spermatozoa in the tract of the same female at the one oestrus (Breed, 1990). The present investigation is an extension of this work and was performed to determine (a) the number and morphology of spermatozoa that reach the higher regions of the female reproductive tract after ejaculation and (b) whether ejaculations from two males can occur in one female at the same oestrous period.

\section{Materials and Methods}

Groups of 3-6 adult male and 3-5 adult nonpregnant female hopping mice, Notomys alexis, were selected from the breeding colony when they became available and were placed in a cage $57 \times 35 \times 15 \mathrm{~cm}$ where the two sexes were separated by a wire mesh partition. Ten or more days later, all the females were primed with 20-30 iu pregnant mares' serum gonadotrophin (PMSG) and 60-74 h later $20 \mathrm{iu}$ human chorionic gonadotrophin (hCG) was administered. These injections were so timed that the lights of the animal room went out 9-10 h after the hCG injection. Shortly after the beginning of the dark period, the barrier partition was removed and a transparent plastic lid was placed on top of the cage which was placed beneath a low-light-intensity camera. All individual males and females had a small amount of hair removed from a specific region of their body so that they could be individually identified.

The behaviour of the group of animals was continuously recorded on video tapes for 6-10 h after the partition was removed. Periodically, after the start of the experiment, vaginal lavages were obtained from the females, placed on microscope slides and observed under phase contrast for spermatozoa. The numbers of motile and immotile spermatozoa were estimated and recorded.

At the end of the experiment, females that had spermatozoa in their lavages and males observed locking with these females were killed. Some of the other animals were used for further mating tests. From the killed females the reproductive tract was carefully dissected out and immersed in $10 \%$ buffered formalin. One ovary, associated oviduct, and uterotubal junction were subsequently removed, dehydrated, and embedded in paraffin wax. Serial 7-10- $\mu \mathrm{m}$ sections were cut, placed on histological slides, and stained with haematoxylin and eosin. These were then inspected using bright field optics and, if spermatozoa were found in the oviduct, the total number was counted and those which lay on their lateral surfaces were allotted to specific morphological categories. The numbers of spermatozoa recorded were those that occurred in the duct cranial to the site at which the uterine epithelium changes to that of the oviduct.

\section{Results}

Thirty-six groups of animals were set up and tested for mating. On replaying the tapes after the completion of the tests, 19 tests had at least one pair that locked and in which spermatozoa had been found in the vaginal lavage of at least one female.

The mean duration of locking between males and females when insemination was known to have taken place was $101 \mathrm{~s}$ (SD $137 \mathrm{~s}, n=23$, range 3-553 s); this did not differ significantly from the duration of locking when insemination was not detected. Most locks lasted $<100 \mathrm{~s}$, but occasionally locks of $\sim 500 \mathrm{~s}$ took place. 
In 9 tests in which an insemination occurred, only a single locking took place, whereas in the other 10 tests at least one female locked 2 or more times, 2 of these tests had 2 females locking 2 or more times (Table 1). Of the 9 females that locked twice, 6 locked with different males and 3 locked with the same male. Of the two females that locked 3 times, one locked with 3 males and the other with 2 (i.e. the last 2 locks involved the same male). The remaining female locked 6 times, twice with a different male and 4 times with the same male. Insemination of this female occurred only after the last 2 locks with the same male (Table 1). In some cases it was not known whether insemination occurred at the first and/or the second lock. However, there were 7 occasions when a female was known to have been inseminated at the first lock, as a vaginal lavage was taken in which spermatozoa were found, before the second and any subsequent locks took place. On 3 occasions (Exp. numbers 6, 21 and 34), the second lock was with a different male and on all occasions motile spermatozoa were found after the second lock as well. The interval between the 2 locks in these 3 females was 386,263 , and $133 \mathrm{~min}$. In 2 of these cases, immotile spermatozoa were observed in a vaginal lavage taken shortly before the second lock. In the third case, the 2 locks were $263 \mathrm{~min}$ apart and, since the longest time when motile sperm have been found in a lavage is $205 \mathrm{~min}$ after insemination, it is highly likely that 2 inseminations of motile spermatozoa occurred in this female as well.

In the females in which there were 2 or more locks, the first lock that took place occurred between $9 \mathrm{~h} 50 \mathrm{~min}$ and $19 \mathrm{~h} 17 \mathrm{~min}$ after the hCG injection. In the 3 females in Exp. numbers 6, 21 and 34 , the first of the 2 locks occurred at $9 \mathrm{~h} 50 \mathrm{~min}, 15 \mathrm{~h} 12 \mathrm{~min}$, and $12 \mathrm{~h} 39 \mathrm{~min}$ after hCG administration, respectively (see Table 1 ).

Numbers and morphology of spermatozoa in the isthmus of one of the two oviducts were determined for 6 females that were killed between $2 \mathrm{~h}$ and $10 \mathrm{~h} 7 \mathrm{~min}$ after mating (Table 2). There were 145 spermatozoa in the oviduct of the female killed $2 \mathrm{~h}$, and 397 sperm in the oviduct of the female killed $10 \mathrm{~h} 7 \mathrm{~min}$, after locking. However, in the 2 females killed $4 \mathrm{~h} 41 \mathrm{~min}$ and $4 \mathrm{~h} 55 \mathrm{~min}$ after a single locking, 1095 and 2567 spermatozoa were present in the oviduct, whereas 8352 spermatozoa were present in the oviduct of a female that locked $5 \mathrm{~h} 5 \mathrm{~min}$ and $6 \mathrm{~h} 46 \mathrm{~min}$ before death; this last female may have been inseminated twice.

In all 6 females, a range of morphological types of spermatozoa were found in the isthmus of the oviduct (Table 2) although only $13-55 \%$ of the total sperm population were so orientated that their head morphology could be determined; $20-38 \%$ of spermatozoa had a straight or slightly curved, apical hook, whereas in $26-50 \%$ of spermatozoa the apical hook was distinctly curved. One female (animal no. 889 13) had an abundance of 3 distinct morphological types of spermatozoa, including one type (type B) that was uncommon in the isthmus of the other females and another (89 10 ) had an abundance of type A, which was rare in the other cases. In all but one female, which had only 397 spermatozoa in the isthmus, $7-17 \%$ of spermatozoa had no apical hook.

\section{Discussion}

Over the last 10 years, several studies have indicated an association between relative testis size and breeding system. In primates, species occurring in single-male breeding groups tend to have smaller relative testis mass than those with multimale breeding groups (Short, 1979, 1980; Harcourt et al., 1981; Harvey \& Harcourt, 1984). Such differences in testis size are thought to be due to greater intermale sperm competition and/or higher copulatory frequencies in males in the multimale breeding groups. Møller $(1988,1989)$ has shown that species with relatively large testes tend to have higher daily sperm production rates, greater sperm stores, and 'better quality' ejaculates.

Amongst rodents, no such similar clear-cut relationship has yet been found between testis size and breeding system. Two recent studies on species of voles (Microtus and Clethrionomys species) have shown that those with a polygynous mating system with male territories and presumably single-male breeding units have small testes, whereas species that mate promiscuously, where sperm competition is likely to occur, have larger testes. However, a species that is considered to be 


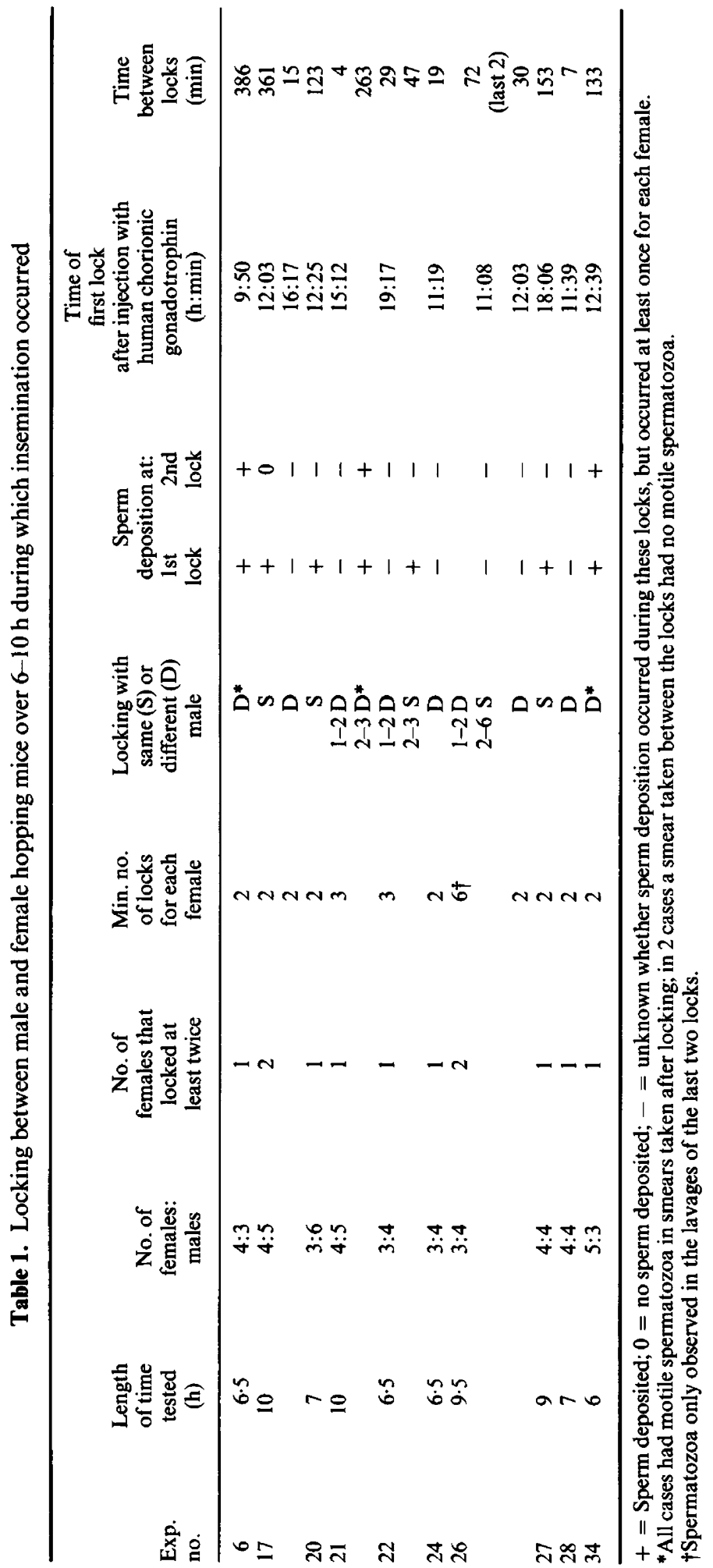




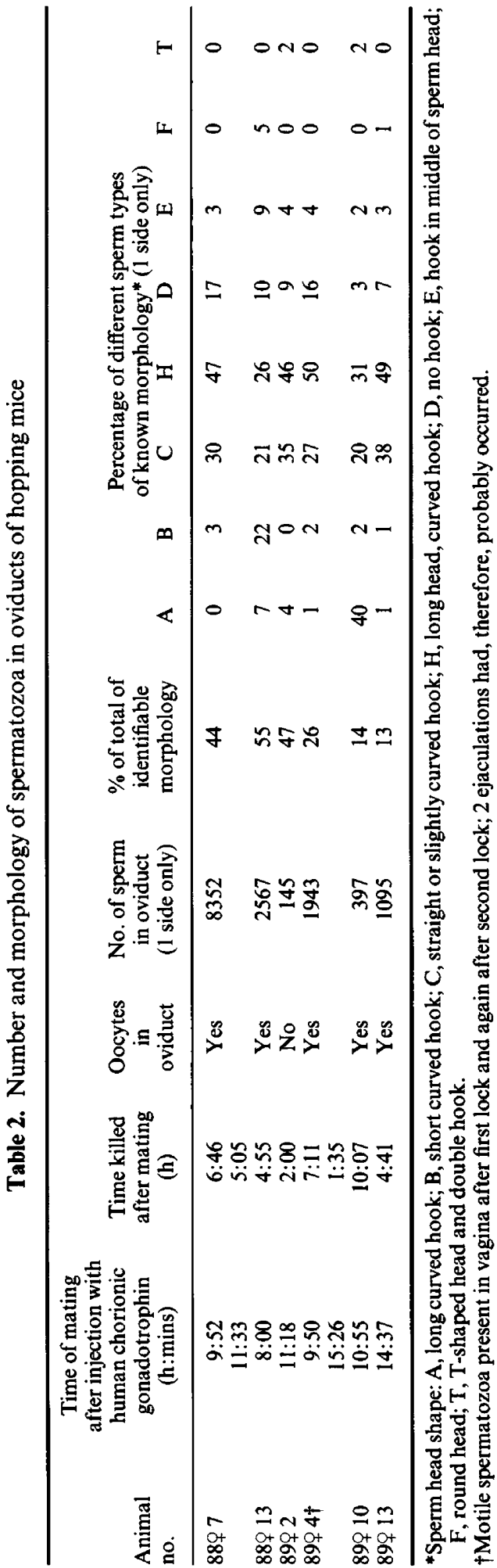


generally monogamous, the prairie vole ( $M$. ochrogaster) also had fairly large testes (Heske \& Ostfeld, 1990; Pierce et al., 1990) although there is some evidence that individuals of this species may sometimes, especially in winter, form complex breeding units (Getz et al., 1987). Pierce et al. (1990) point out that their data are nevertheless probably consistent with relatively large testes occurring in species that exhibit multiple-male mating of a female at oestrus.

Amongst the Australian conilurine rodents, there are huge differences in absolute and relative testis size; 4 of 5 extant Notomys species having testes of only $\sim 0.2 \%$ of body mass (Breed, 1982, 1986), which is about an order of magnitude smaller than the mean testis mass of mammals of comparable body size (Kenagy \& Trombulak, 1986). These species also have small epididymides and low epididymal sperm stores (Breed, 1982, 1986; Peirce \& Breed, 1989) and studies on sperm morphology of one of these species, $N$. alexis, have shown a high degree of pleiomorphism of acrosome, nucleus and overall sperm head shape (Breed \& Sarafis, 1983; Suttle et al., 1988). From various other aspects this species ranks very high on Dewsbury's scale of predictability of monogamy for muroid rodents (Dewsbury, 1981; Dewsbury \& Hodges, 1987). However, within the laboratory environment, individuals of this species exhibit a high degree of sociality between all members of any one group of males and females (Happold, 1976). It was suggested that the small testes and low numbers of spermatozoa in males of this species may be causally related to the greater aggressiveness of the female, such that, once an insemination by one of the males in the group had occurred, the female would prevent the other males from mating with her; such behaviour was thus thought to reduce the chance of intermale sperm competition within the female tract (Breed, 1986; Suttle et al., 1988). However, in a recent study on copulatory behaviour of gonadotrophin-primed laboratory animals, a female sometimes locked with 2 males cohabiting with her, although there was no evidence that 2 separate ejaculations ever occurred (Breed, 1990). This could, in part, have been due to either lack of sperm production by at least one of the males, or coital inadequacy between the pair, or the inability to detect spermatozoa in the lavage.

In this study, we repeated a similar series of tests on groups of adults of both sexes, but performed vaginal lavages more frequently to determine whether more than one insemination of the female occurs at the same oestrus. Unfortunately, the occurrence, or lack, of insemination could not be determined from the duration of the lock between the pair or from any observed behaviour of the pair during coitus. However, 9 instances were observed when a female locked with 2 , and one with 3 , males. In at least 2 , and probably 3 , separate tests both males that locked with the one female ejaculated as shown by the presence of highly motile spermatozoa after both locks; the inseminations occurred 133, 263, and $386 \mathrm{~min}$ apart. Clearly, therefore, within the confines of this laboratory setting, individual female hopping mice, after being primed with gonadotrophins, can sometimes be inseminated by 2 males at one oestrus. There is thus a potential for intermale sperm competition to occur within the female reproductive tract of these animals.

In a previous investigation we found that hopping mice usually ovulate $10-11 \mathrm{~h}$ after administration of hCG (W. G. Breed, L. MacGregor \& S. P. Flaherty, unpublished observations) and the 3 females that had 2 inseminations mated between $9 \mathrm{~h} 50 \mathrm{~min}$ and $15 \mathrm{~h} 16 \mathrm{~m} \mathrm{n}$ after the hCG was administered. As the second insemination did not occur until at least 133 min after the first, all the oocytes may have been fertilized by the time the second ejaculation took place.

Hopping mice have a number of other divergent features of their reproductive tracts apart from small testes and epididymides. One such feature is the structure of the ductus deferens in which a significant proportion of the extratesticular sperm population reside (Breed, 1981, 1982; Peirce \& Breed, 1989). Preliminary observations have shown that, $1-2 \mathrm{~h}$ after a single ejaculation, the sperm population of the cauda has not been depleted, but the number in the vas is somewhat reduced (V. Bradtke \& W. G. Breed, unpublished observations). Thus, this extratesticular storage site for spermatozoa appears to enhance the storage capacity of the extratesticular ducts in this species and is the site from which sperm emission occurs during at least the first ejaculation. A second divergent feature of the reproductive tract of these animals that may be of significance is the structure of the cervix, which has a luminal size and mucosal and muscular wall that is little different in thickness 
from that of the vagina. It is quite unlike the large, bulky, highly fibrous cervix that occurs in most murids (Breed, 1985). The occurrence of spermatozoa in vaginal lavages after locking indicates that vaginal insemination takes place, but the absence of a large cervix may result in a high percentage of the ejaculate reaching the cranial region of the uterus. The present study shows that, by $4 \mathrm{~h}$ after insemination, at least 1000 spermatozoa have populated the isthmus, which is similar to the number of spermatozoa that reach this region in laboratory mice after mating (Nicol \& McLaren, 1974; Tessler \& Olds-Clarke, 1981). It seems likely, therefore, that the number of spermatozoa in the isthmus of the oviduct after one ejaculation is similar in the two species in spite of considerable differences in testis size. Such differences in proportion of spermatozoa gaining access to the oviduct may, at least in part, be due to the highly divergent structure of the lower region of the female tract, more efficient sperm transport occurring in hopping mice.

In laboratory mice, the uterotubal junction acts as a barrier preventing grossly abnormal spermatozoa from entering the oviduct (Krzanowska, 1974). However, in hopping mice, differential counts of spermatozoa in the isthmus showed that a range of morphological types occurs. No selection for any particular type thus appears to take place at the uterotubal junction, nor is it likely that certain morphological types become selectively trapped in the coagulum that forms in the lower uterus and cervix (Breed, 1990). This observation thus argues against the view of Baker $\&$ Bellis (1988) that some sperm types may be destined for some function other than the fertilization of the eggs.

This study has demonstrated that, when groups of hopping mice live together in one cage, more than one of the males can sometimes inseminate a primed female at around the time of oestrus. Sperm competition could therefore occur even though the animals have remarkably small testes and low sperm stores. There may, however, be efficient transport of spermatozoa as a result of the highly divergent structure of the cervix and, after a single ejaculate, at least 1000 spermatozoa of a range of morphological types populate the isthmus of the oviduct. In a recent concurrent study, in which two genetically distinct male hopping mice inhabited the same cage as a single female undergoing natural cycles, no multiple paternity in any one litter was found, although this was evident in a few litters of a second conilurine rodent species that has large testes (W. G. Breed \& M. Adams, unpublished). Multiple paternity is, however, only likely to occur if both inseminations take place around the time of ovulation (Huck et al., 1989; Ginsberg \& Huck, 1989). In the present study, where there were two inseminations, the first took place close to or shortly after the expected time of ovulation and the second at least 133 min later. It would seem unlikely, therefore, that multiple paternity would have resulted if any of these matings had been allowed to go to term as all the eggs would probably have been fertilized by the time the second ejaculation took place.

Observations of hopping mice show that frequent mounting takes place between all males and females in any one group and that much of the mounting has a social, rather than sexual, function (Happold, 1976). During the mating tests in the present study it appeared that the male most likely to gain intromission and inseminate a particular female is the individual that is the most persistent and has the fastest locomotor activity. Such behavioural features may be important in intermale competition of these animals.

This project was financed by an Australian Research Council grant (Number A 18616294) to the senior author. We should like to thank E. Batty for assistance with the histology, E. Breed for typing the manuscript and D. Schaller for stimulating discussions on the behaviour of the animals.

\section{References}

Baker, R.R. \& Bellis, M.A. (1988) 'Kamikaze' sperm in mammals? Anim. Behav. 36, 936-939.

Birkhead, T.R. (1987) Sperm competition in birds. Trends Ecol. Evol. 2, 268-272.

Birkhead, T.R. \& Hunter, F.M. (1990) Mechanisms of sperm competition. Trends Ecol. Evol. 5, 48-52.
Breed, W.G. (1981) Unusual anatomy of the male reproductive tract in Notomys alexis (Muridae). $J$. Mammal. 62, 373-375.

Breed, W.G. (1982) Morphological variation in the testes and accessory sex organs of Australian rodents in the genera Pseudomys and Notomys. J. Reprod. Fert. 66, 607-613. 
Breed, W.G. (1985) Morphological variation in the female reproductive tract of Australian rodents in the genera Pseudomys and Notomys. J. Reprod. Fert. 73, 379-384.

Breed, W.G. (1986) Comparative morphology and evolution of the male reproductive tract in the Australian hydromyine rodents (Muridae). J. Zool. Lond. A 209, 607-629.

Breed, W.G. (1990) Copulatory behaviour and coagulum formation in the female reproductive tract of the Australian hopping mouse Notomys alexis. $J$. Reprod. Fert. 88, 17-24.

Breed, W.G. \& Sarafis, V. (1983) Variation in sperm head morphology in the Australian rodent Notomys alexis. Aust. J. Zool. 31, 313-316.

Dewsbury, D.A. (1981) An exercise in the prediction of monogamy in the field from laboratory data on 42 species of muroid rodents. Biologist 63, 138-162.

Dewsbury, D.A. (1984) Sperm competition in muroid rodents. In Sperm Competition and the Evolution of Animal Mating Systems, pp. 547-571. Ed. R.L. Smith. Academic Press, New York.

Dewsbury, D.A. (1988) A test of the role of copulatory plugs in sperm competition in deer mice (Peromyscus maniculatus). J. Mammal. 69, 854-857.

Dewsbury, D.A. \& Hodges, A.W. (1987) Copulatory behavior and related phenomena in spiny mice (Acomys cahirinus) and hopping mice (Notomys alexis). J. Mammal, 68, 49-57.

Getz, L.L., Hofmann, J.E. \& Carter, C.S. (1987) Mating system and population fluctuations of the prairie vole, Microtus ochrogaster. Am. Zool. 27, 909-920.

Ginsberg, J.R. \& Huck, U.W. (1989) Sperm competition in mammals. Trends Ecol. Evol. 4, 74-79.

Happold, M. (1976) Social behaviour of conilurine rodents (Muridae) of Australia. Z. Tierpsychol. 40, 113-182.

Harcourt, A.H., Harvey, P.H., Larson, S.G. \& Short, R.V. (1981) Testes weight, body weight and breeding system in primates. Nature, Lond. 293, 55-57.

Harvey, P.H. \& Harcourt, A.H. (1984) Sperm competition, testes size, and breeding system in primates. In Sperm competition and the Evolution of Animal Mating Systems, pp. 589-600. Ed. R.L. Smith. Academic Press, New York.

Heske, E.J. \& Ostfeld, R.S. (1990) Sexual dimorphism in size, relative size of testes, and mating systems in North American voles. J. Mammal. 71, 510-519.

Huck, U.W., Quinn, R.P. \& Lisk, R.D. (1985) Determinants of mating success in the golden hamster (Mesocricetus auratus) IV. Sperm competition. Behav. Ecol. Sociobiol. 17, 239-252.

Huck, U.W., Tonias, B.A. \& Lisk, R.D. (1989) The effectiveness of competitive male inseminations in golden hamsters, Mesocricetus auratus, depends on an interaction of mating order, time delay between males, and the time of mating relative to ovulation. Anim. Behav. 37, 674-680.

Kenagy, G.J. \& Trombulak, S.C. (1986) Size and function of mammalian testes in relation to body size. $J$. Mammal. 67, 1-22.

Krzanowska, H. (1974) The passage of abnormal spermatozoa through the uterotubal junction of the mouse. J. Reprod. Fert. 38, 81-90.

Moller, A.P. (1988) Ejaculate quality, testes size, and sperm competition in primates. J. Human Evol. 17, 479-488.

Møller, A.P. (1989) Ejaculate quality, testes size, and sperm production in mammals. Funct. Ecol. 33, 418-422.

Nicol, A. \& McLaren, A. (1974) An effect of the female genotype on sperm transport in mice. J. Reprod. Fert. $39,421-424$.

Parker, G.A. (1984) Sperm competition and the evolution of animal mating strategies. In Sperm Competition and the Evolution of Animal Mating Systems, pp. 1-60. Ed. R.L. Smith. Academic Press, New York.

Peirce, E.J. \& Breed, W.G. (1987) Cytological organization of the seminiferous epithelium in the Australian rodents Pseudomys australis and Notomys alexis. $J$. Reprod. Fert. 80, 91-103.

Peirce, E.J. \& Breed, W.G. (1989) Light microscopical structure of the excurrent ducts and distribution of spermatozoa in the Australian rodents Pseudomys australis and Notomys alexis. J. Anat. 162, 195-213.

Pierce, J.D. Jr, Ferguson, B., Salo, A.L., Sawrey, D.K., Shapiro, L.E., Taylor, S.A. \& Dewsbury, D.A. (1990) Patterns of sperm allocation across successive ejaculates in four species of voles (Microtus). J. Reprod. Fert. 88, 141-149.

Short, R.V. (1979) Sexual selection and its component parts, somatic and genital selection, as illustrated by man and the great apes. Adv. Stud. Behav. 9, 131-158.

Short, R.V. (1980) The origin of human sexuality. In Reproduction in Mammals, vol. 8, pp. 1-41. Eds C. R. Austin \& R. V. Short. Cambridge University Press, Cambridge.

Suttle, J.M., Moore, H.D.M., Peirce, E.J. \& Breed, W.G. (1988) Quantitative studies on variation in sperm head morphology of the hopping mouse Notomys alexis. J. exp. Zool. 247, 166-171.

Tessler, S. \& Olds-Clarke, P. (1981) Male genotype influences sperm transport in female mice. Biol. Reprod. 24, 806-813.

Voss, R. (1979) Male accessory glands and the evolution of copulatory plugs in rodents. Occ. Pap. Mus. Zool. Univ. Mich. 689, 1-17.

Received 29 October 1990 